\title{
Ethical Issues Relating to Faith Healing Practices in South Asia: A Medical Perspective
}

Siddharth Sarkar, Sreekanth Sakey and Shivanand Kattimani*

Department of Psychiatry, Jawaharlal Institute of Postgraduate Medical Education and Research, Puducherry, India

${ }^{*}$ Corresponding author: Shivanand Kattimani, Associate Professor, Department of Psychiatry, JIPMER, Dhanvantari nagar, Pondicherry-605 006, India, Tel: 0413-2296402; E-mail: drshivanand@gmail.com

Rec date: Apr 22, 2014, Acc date: Jul 23, 2014, Pub date: Jul 25, 2014

Copyright: @ 2014 Sarkar S. This is an open-access article distributed under the terms of the Creative Commons Attribution License, which permits unrestricted use, distribution, and reproduction in any medium, provided the original author and source are credited.

\begin{abstract}
Despite growing access to modern medicine, faith healing practices still continue to be prevalent in South Asia. Faith healing practices include a wide range of activities like performing elaborate rituals, recommending amulets, suggestion for wearing specific rings, branding with rods, chaining in temples, exorcism of jinn and ghosts, animal sacrifices and others. In this paper, faith healing practices are evaluated on the principles of medical ethics using specific examples. The principle of autonomy, beneficence, non-maleficence and justice are explored. The authors draw inference that while some practices may be unacceptable and should be curtailed, the overall institution of faith healing might be useful for some people.
\end{abstract}

Keywords: Faith healing; Treatment; Ethics; Culture; South Asia; India

\section{Introduction}

South Asia is probably the most densely populated area in the world, and has a rich historical and diverse cultural background. With time, the region has seen gradual improvement in accessibility to medical services. Traditional forms of treatment are being supplanted by modern medicine. Despite the attempts at providing access to modern medicine to the entire population, faith healing practices still continue to be fairly prevalent in the region [1-3]. Cultural acceptance of the systems of faith healing, coupled with the relative lack of robust healthcare infrastructure in the region probably contributes to the continuation of these forms of treatment [4].

Before further exploration of the ethical aspects relating to faith healing, it would be meaningful to characterize what constitutes faith healing. Different authorities and researchers have used the term 'faith healing' in different contexts. While some may consider special prayers and services as faith healing, others construe it to be specialized rituals that are completed in a specific manner [5]. For the purposes of this paper, we consider faith healing as community accepted specific rituals carried out by designated figures with the aim of relieving symptoms of distress. The procedures that are carried out by faith healers include a wide range of activities like performing elaborate rituals (puja), recommending amulets (tabeez), suggestion for wearing specific rings, branding with rods, chaining in temples, exorcism of jinn and ghosts, animal sacrifices and other similar practices.

This paper seeks to discuss the ethical aspects of faith healing practices in South Asia from the perspective of a medical professional. It tries to address how these practices can be viewed objectively by physicians and surgeons when faced with the situation of a patient or his/her relative intending to seek faith healer treatment. The paper does not seek to address religious and spiritual practices like prayers and religious ceremonies in relation to general well-being. The present work also refrains from discussion about superstitious beliefs in the community. Parts of the perspective might appear non-evidence based due to lack of systematic medical evidence on the issue.

\section{Who goes to Faith Healers and Why?}

People from a variety of backgrounds approach faith healers for treatment $[4,6]$. Individuals from both rural and urban residence seek services of faith healers [3]. Utilization of such practices seems to be more common in the lower socio-economic strata, or where access to other forms of treatment is difficult $[7,8]$. Faith healing practices may be resorted to by those expecting a miracle cure for conditions like cancers, where effective treatment might not be available through the regular treatment modalities [9]. People might also seek help from faith healers for conditions like infertility, which might make them feel embarrassed to discuss in a medical setting. Insistence or suggestions by relatives and well-wishers maybe another reason why such faith healing practices are sought [10]. Belief about supernatural causation of illnesses are deeply entrenched in the society, especially for illnesses which do not have a clearly defined etiology $[6,11]$. Lack of knowledge and superstitious beliefs may also predispose an individual to seek treatment from faith healers $[8,12]$. Covert and overt propaganda by the faith healers through pamphlets, posters and other means emphasizing their claims may induce vulnerable individuals to seek such care [13]. It must be highlighted that all persons who seek cure through faith healers do not continue that pathway-of-care indefinitely $[3,14,15]$, probably finding it expensive or unhelpful. At the same time, many clients consider themselves to be satisfied by the help afforded through such practices $[3,6]$.

\section{Efficacy and Potential Harms}

The efficacy of the faith healing practices may be considered a matter of debate. Some authorities may consider these practices are useful in reducing the symptoms of distress through the placebo effect [16], especially for conditions like depression. For a placebo effect to work, the individual should believe in the placebo. The rituals and ceremonies surrounding the faith healing practices provide a persuasive placebo effect, which has been suggested to lead to patient improvement [17]. However, from another perspective, placebo effect is unlikely to work for disorders like cancers, and use of faith healing practices may do more harm than good.

Some of these faith healing practices are associated with potential harms. Sometimes, practices which include chaining and involuntary restraint in temples may lead to lacerations, fractures and wounds. Conduct of ceremonial rituals in closed environment may lead to inadvertent carbon monoxide poisoning [18]. Branding i.e. application 
of hot iron rod on the body for the purpose of treatment, can result in permanent disfigurement and secondary wound infections [19]. Involvement into prolonged faith healer treatment for conditions with effective medical treatment delays appropriate care, and can lead to the complications due to the illness process. Apart from the above, expensive rituals may drain the financial resources of the treatment seeker.

\section{Ethical Issues}

The issues relating to such faith healing practices can be looked from the lens of general principles of medical ethics, i.e. autonomy, beneficence, non-maleficence and justice [20]. The first and the foremost is the principle of autonomy. Though the patients and/or their family members often exercise autonomy in making a decision on whether to seek treatment from faith healers, the procedure of faith healing is quite prescriptive and does not provide a menu of options to choose from. Coercion might exist in some forms of faith healing practices. Some instances of temple healing involving seclusion and restraint of individuals, and contravene the provision of least restrictive care [8]. At times, decisions for seeking such are made by the family members and the individual just complies with the faith healing procedure suggested [6]. At the same time, it must also be remarked that 'modern' medicine has also evolved over the decades from a paternalistic attitude in the past to a more collaborative informed decision-making process of present times.

Beneficence and nonmaleficence are next two ethical principles often considered together. The motivation of faith healers to treat patients probably includes altruism, apart from potential of monetary gain and rise in social stature. Many patients are benefitted and some do get personalized attention which might be difficult to obtain in busy emergency setting of public health-care services in South Asia. It has been seen that for certain disorders, patients and their family members are quite satisfied by the treatment offered by the faith healers [21]. Some faith healers are able to judge what types of problems are unlikely to get better by their treatment, and promptly refer such cases to medical settings to remain in good grace of the clientele [3]. However, there are other circumstances where use of faith healing techniques may have adverse consequences. Subjecting individuals to rigorous rituals like fasting for long duration may be detrimental to patients with diabetes or malnourishment. Similarly, as discussed above, procedures like branding with a hot iron-rod may have unintended malefic consequences like wounds. Efficacy of these practices is unproven, and whether such practices constitute a form of treatment at all can be debated.

From the standpoint of justice, i.e. allocating resources uniformly across all strata, treatment through faith healers might hold some promise. It has been noted that the scarce healthcare resources in South Asian countries are not equitably distributed [12]. The users of modern medical services are primarily located in urban areas. In this situation, faith healers might provide an easy and acceptable alternative provision of healthcare services to the community. At the same time, whether faith healers provide any amount of effective care needs to be considered. Ease of access to care does not override the requirement of beneficence and nonmaleficence in this situation. Also, though some forms of faith healing like rituals in temples may provide access to many, specialized services like yagnas or rings to ward off evil spirits may be quite expensive and out of reach of the ordinary.

Other aspects in relation to treatment by faith healers include issues of confidentiality and double agentry. Often the services of faith healer are recruited by a close relative and not the patient himself/herself. The patient may share some information with the faith healer, but not with the close family member. In this circumstance, whether the faith healer maintains the confidentiality of the patient, or shares information with those who bring the patient may be a contentious issue. Each situation may be unique, and requires the discretion of the faith healer to judge the circumstance and decide accordingly. Clinicians dealing with patients might be forced to encounter issues relating to faith healing practices when patient/family request to additionally perform rituals along with continuation of the medical treatment. Such requests may generate counter-transference feelings and conflict in the mind of the physician. In such situations, it might be better to decide considering patient/family wishes, the medical disorder being treated and the faith healing practice being proposed. To further elaborate the issues, few case examples of ethical challenges with respect to faith healing are discussed in Table 1.

The issue of faith healers being needed in the current society in South Asia can be viewed from utilitarian and deontological ethical perspectives. Utilitarian perspective of what works best suggests that faith healers should continue their practice as they are beneficial to some individuals [3]. Being allowed to work in regulated manner ensuring that they do no harm may be an acceptable course of action. Deontological principles suggest that ethical choices are uniform and not context based. From such a perspective, faith healing practices should not be tolerated if they are proved to be harmful. However, due to the heterogeneity of conditions treated by faith healing practices and the wide variety of practices themselves, it may be difficult to generalize about such practices.

Case 1: A middle aged lady being given an amulet/ring for treatment of depressive symptoms

\begin{tabular}{|l|l|}
\hline Autonomy & $\begin{array}{l}\text { The lady would have much choice to continue wearing } \\
\text { amulet/ring or not. Autonomy unlikely to be significantly } \\
\text { impaired }\end{array}$ \\
\hline Beneficence & $\begin{array}{l}\text { The amulet/ring might have been given with the intention to } \\
\text { do good }\end{array}$ \\
\hline $\begin{array}{l}\text { Non- } \\
\text { maleficence }\end{array}$ & $\begin{array}{l}\text { No direct or indirect harm is likely to be due to the wearing } \\
\text { of amulet/ring. }\end{array}$ \\
\hline Justice & $\begin{array}{l}\text { Access to treatment in a place and form which is acceptable } \\
\text { to the person concerned. Likely to work through placebo } \\
\text { effect. }\end{array}$ \\
\hline
\end{tabular}

Case 2: An man with long standing alcohol dependence being subjected to 'jhaad phook' for treatment of jaundice resulting from liver dysfunction

\begin{tabular}{|l|l|}
\hline Autonomy & $\begin{array}{l}\text { The autonomy is likely to be constrained during the period } \\
\text { of the procedure lasting minutes to hours, and the patient } \\
\text { possibly would not allowed to leave. Likely to be brought by } \\
\text { the family members. }\end{array}$ \\
\hline Beneficence & $\begin{array}{l}\text { The procedure conducted to remove the evil spirits might be } \\
\text { done with a conceptualization to do benefit. Such benefits } \\
\text { are unproven }\end{array}$ \\
\hline $\begin{array}{l}\text { Non- } \\
\text { maleficence }\end{array}$ & $\begin{array}{l}\text { The procedure is not likely to find the cause of jaundice or } \\
\text { treat it in any manner. Indirect harm if it causes delay to } \\
\text { appropriate treatment in a medical facility }\end{array}$ \\
\hline Justice & $\begin{array}{l}\text { Might be a more accessible form of treatment, but lack of } \\
\text { any efficacy makes it unhelpful to the community as a } \\
\text { whole. }\end{array}$ \\
\hline
\end{tabular}




\begin{tabular}{|c|c|}
\hline Autonomy & $\begin{array}{l}\text { Involuntarily chaining and branding impairs the autonomy of } \\
\text { the patient. }\end{array}$ \\
\hline Beneficence & $\begin{array}{l}\text { Beneficence towards the patients cannot be clearly } \\
\text { established. May appear like a punitive measure to control } \\
\text { aberrant behaviour. }\end{array}$ \\
\hline $\begin{array}{l}\text { Non- } \\
\text { maleficence }\end{array}$ & $\begin{array}{l}\text { The procedure is potentially harmful to the patient, inflicting } \\
\text { pain and may lead to secondary infection. Withholding } \\
\text { potentially beneficial medications if additional psychiatric } \\
\text { services are not provided. }\end{array}$ \\
\hline Justice & $\begin{array}{l}\text { Chaining of patient may be comparable to institutionalization } \\
\text { of the patient in a long term facility. But the quality of care is } \\
\text { likely to be better in a psychiatric facility. Might serve the } \\
\text { community for a while, but in view of effective medications } \\
\text { available to control schizophrenia, such acts would be } \\
\text { considered unjustified }\end{array}$ \\
\hline
\end{tabular}

Table 1: Ethical principles applied in select case scenarios

Another point of concern which may arise in the future is when someone attempts to validate the benefits/efficacy of faith healing practices through the scientific method. As of present, scientific evidence about faith healing practices is lacking, barring a few anecdotal reports. But lack of evidence of efficacy does not equate to evidence of lack of efficacy. It is interesting to speculate how ethics committees would evaluate such proposals of rigorously testing faith healing practices, if at all they arise. While some committees might reject such proposals outright, others might be interested in allowing evaluation ensuring patient safety and dissecting out placebo effects. How informed consent is obtained in such studies would be a crucial question. This is because telling a prospective participant that no clear demonstrable mechanisms explain efficacy might deter participation and erode out 'faith' in the treatment. Yet, progressing from anecdotal to systematic evidence about faith healing would need further robust research.

\section{Conclusion}

The present discussion suggests that continuation of faith healing practices is likely to occur due to the cultural acceptance and societal need. Many of the practices are potentially dangerous to the person concerned, while at times some practices may be considered helpful and beneficial. The practical application of these procedures requires a look at the ethical issues relating to autonomy, beneficence, nonmaleficence and justice. Some of the practices in select situations can be complementary to the usual medical care and need not be considered antagonistic to the objectives of modern medicine.

\section{References}

1. Ahmed SM, Hossain MA, Chowdhury MR (2009) Informal sector providers in Bangladesh: how equipped are they to provide rational health care? See comment in PubMed Commons below Health Policy Plan 24: 467-478.

2. Balarajan Y, Selvaraj S, Subramanian SV (2011) Health care and equity in India. See comment in PubMed Commons below Lancet 377: 505-515.
3. Schoonover J, Lipkin S, Javid M, Rosen A, Solanki M, et al. (2014) Perceptions of traditional healing for mental illness in rural gujarat. See comment in PubMed Commons below Ann Glob Health 80: 96-102.

4. Chadda RK, Agarwal V, Singh MC, Raheja D (2001) Help seeking behaviour of psychiatric patients before seeking care at a mental hospital. See comment in PubMed Commons below Int J Soc Psychiatry 47: 71-78.

5. Gillon R (1994) Medical ethics: four principles plus attention to scope. See comment in PubMed Commons below BMJ 309: 184-188.

6. Mishra N, Nagpal SS, Chadda RK, Sood M (2011) Help-seeking behavior of patients with mental health problems visiting a tertiary care center in north India. See comment in PubMed Commons below Indian J Psychiatry 53: 234-238.

7. Kishore J, Gupta A, Jiloha RC, Bantman P (2011) Myths, beliefs and perceptions about mental disorders and health-seeking behavior in Delhi, India. See comment in PubMed Commons below Indian J Psychiatry 53: 324-329.

8. Campion J, Bhugra D (1997) Experiences of religious healing in psychiatric patients in south India. See comment in PubMed Commons below Soc Psychiatry Psychiatr Epidemiol 32: 215-221.

9. Arora RS, Eden T, Pizer B (2007) The problem of treatment abandonment in children from developing countries with cancer. See comment in PubMed Commons below Pediatr Blood Cancer 49: 941-946.

10. Qidwai W, Azam SI, Ali SS, Ayub S (2002) The utilization of services of health care providers among patients presenting to family physicians at a teaching hospital in Karachi, Pakistan. See comment in PubMed Commons below J Pak Med Assoc 52: 269-272.

11. Grover S, Patra BN, Aggarwal M, Avasthi A, Chakrabarti S, et al. (2014) Relationship of supernatural beliefs and first treatment contact in patients with obsessive compulsive disorder: An exploratory study from India. See comment in PubMed Commons below Int J Soc Psychiatry .

12. Pal SK, Sharma K, Prabhakar S, Pathak A (2008) Psychosocial, demographic, and treatment-seeking strategic behavior, including faith healing practices, among patients with epilepsy in northwest India. Epilepsy Behav. 13: 323-332.

13. Keshavan MS, Narayanan HS, Gangadhar BN (1989) 'Bhanamati' sorcery and psychopathology in south India. A clinical study. See comment in PubMed Commons below Br J Psychiatry 154: 218-220.

14. Jain N, Gautam S, Jain S, Gupta ID, Batra L, et al. (2012) Pathway to psychiatric care in a tertiary mental health facility in Jaipur, India. See comment in PubMed Commons below Asian J Psychiatr 5: 303-308.

15. Kar N (2008) Resort to faith-healing practices in the pathway to care for mental illness: a study on psychiatric inpatients in Orissa. Ment Health Relig Cult 11: 720-740.

16. Kalantri SP (2002) Temple healing. Healing temples may breed superstitions. BMJ 325: 968.

17. Raguram R, Venkateswaran A, Ramakrishna J, Weiss MG (2002) Traditional community resources for mental health: a report of temple healing from India. See comment in PubMed Commons below BMJ 325: 38-40.

18. Behera C, Millo TM, Jaiswal A, Dogra TD (2013) Accidental carbon monoxide poisoning during yagya for faith healing--a case report. See comment in PubMed Commons below J Indian Med Assoc 111: 196-197.

19. Kumar S, Kumar PR (2004) Skin branding. See comment in PubMed Commons below J Postgrad Med 50: 204.

20. Saeed K, Gater R, Hussain A, Mubbashar M (2000) The prevalence, classification and treatment of mental disorders among attenders of native faith healers in rural Pakistan. Soc Psychiatry Psychiatr Epidemiol 35:480485

21. Sax W (2014) Ritual healing and mental health in India. See comment in PubMed Commons below Transcult Psychiatry. 